MSC 35G05

DOI: $10.14529 / \mathrm{mmp} 150211$

\title{
COMPUTATIONAL EXPERIMENT FOR ONE MATHEMATICAL MODEL OF ION-ACOUSTIC WAVES
}

A.A. Zamyshlyaeva, South Ural State University, Chelyabinsk, Russian Federation, alzama@mail.ru, A.S. Muravyev, South Ural State University, Chelyabinsk, Russian Federation, gg.amur@gmail.com

In the article the mathematical model of ion-acoustic waves in a plasma in an external magnetic field is studied. This model can be reduced to a Cauchy problem for a Sobolev type equation of the fourth order with polynomially $(A, p)$-bounded operator pencil. Therefore abstract results on solvability of the Cauchy problem for such equation can be used. In the article a theorem on the unique solvability of the Cauchy - Dirichlet problem is mentioned. Based on the theoretical results there was developed an algorithm for the numerical solution of the problem, using a modified Galerkin method. The algorithm is implemented in Maple. The article includes description of this algorithm. It is illustrated by model examples showing the work of the developed program.

Keywords: mathematical model; ion-acoustic waves; Galerkin method.

Introduction. Consider equation

$$
\frac{\partial^{2}}{\partial t^{2}}\left(\frac{\partial^{2}}{\partial t^{2}}+\omega_{B_{i}}^{2}\right)\left(\Delta_{3} \Phi-\frac{1}{r_{D}^{2}} \Phi\right)+\omega_{p_{i}}^{2} \frac{\partial^{2}}{\partial t^{2}} \Delta_{3} \Phi+\omega_{B_{i}}^{2} \omega_{p_{i}}^{2} \frac{\partial^{2} \Phi}{\partial x_{3}^{2}}=0
$$

first obtained by Y.D. Pletner [2], which describes the ion-acoustic waves in a plasma in an external magnetic field. Here $\Delta_{3}$ is a Laplace operator in $\mathbb{R}^{3}$, the function $\Phi$ is a generalized potential of the electric field, the constants $\omega_{B_{i}}^{2}, \omega_{p_{i}}^{2}$ and $r_{D}^{2}$ characterize ion gyrofrequency, Langmuir frequency and the Debye radius, respectively. Transform equation (1) and consider a more general problem.

Let $\Omega=(0, a) \times(0, b) \times(0, c) \subset \mathbb{R}^{3}$. In the cylinder $\Omega \times \mathbb{R}$ consider the Cauchy Dirichlet problem

$$
\begin{gathered}
v(x, 0)=v_{0}(x), \quad v_{t}(x, 0)=v_{1}(x), \\
\frac{\partial^{2} v}{\partial t^{2}}(x, 0)=v_{2}(x), \quad \frac{\partial^{3} v}{\partial t^{3}}(x, 0)=v_{3}(x), \quad x \in \Omega \\
v(x, t)=0, \quad(x, t) \in \partial \Omega \times \mathbb{R}
\end{gathered}
$$

for equation

$$
(\Delta-\lambda) \frac{\partial^{4} v}{\partial t^{4}}+\left(\Delta-\lambda^{\prime}\right) \frac{\partial^{2} v}{\partial t^{2}}+\alpha \frac{\partial^{2} v}{\partial x_{3}^{2}}=0,
$$


describing the ion-acoustic waves in a plasma in a magnetic field, and the negative values of the parameter $\lambda$ do not contradict the physical meaning of this problem. Stochastic mathematical model of ion-acoustic waves in a plasma was considered in [3].

1. Analytical Study of the Mathematical Model of Ion-Acoustic Waves in a Plasma in a Magnetic Field. Introduce the eigenfunctions of the Laplace operator $\Delta$ in the domain $\Omega$ satisfying conditions (3): $\varphi_{k m n}=\left\{\sin \frac{\pi k x_{1}}{a} \sin \frac{\pi m x_{2}}{b} \sin \frac{\pi n x_{3}}{c}\right\}$, where $k$, $m, n \in \mathbb{N}$, and the eigenvalues $\lambda_{k m n}=-\left(k^{2}+m^{2}+n^{2}\right)$. Obviously, the spectrum $\sigma(\Delta)$ is negative, discrete with finite multipicities and thickens only to $-\infty$. Since $\left\{\varphi_{k}\right\} \subset C^{\infty}(\Omega)$, then

$$
\begin{gathered}
\mu^{4} A-\mu^{3} B_{3}-\mu^{2} B_{2}-\mu B_{1}-B_{0}= \\
\sum_{k, m, n=1}^{\infty}\left[\left(\lambda_{k m n}-\lambda\right) \mu^{4}+\left(\lambda_{k m n}-\lambda^{\prime}\right) \mu^{2}-\alpha\left(\frac{\pi n}{c}\right)^{2}\right]<\varphi_{k m n}, \cdot>\varphi_{k m n}
\end{gathered}
$$

where $<\cdot, \cdot>$ is a scalar product in $L^{2}(\Omega)$.

Lemma 1. [4] (i) Let $\lambda \notin \sigma(\Delta)$. Then the pencil $\vec{B}$ is polynomially $(A, 0)$-bounded.

(ii) $(\lambda \in \sigma(\Delta)) \wedge\left(\lambda \neq \lambda^{\prime}\right)$. Then the pencil $\vec{B}$ is polynomially $(A, 1)$-bounded.

(iii) $(\lambda \in \sigma(\Delta)) \wedge\left(\lambda=\lambda^{\prime}\right)$. Then the pencil $\vec{B}$ is polynomially $(A, 3)$-bounded.

Theorem 1. [4] (i) Let $\lambda \notin \sigma(\Delta)$. Then, for arbitrary $v_{0}, v_{1}, v_{2}, v_{3} \in \mathfrak{U}$ there exists a unique solution of problem (2) - (4).

(ii) Let $\lambda \in \sigma(\Delta) u \lambda=\lambda^{\prime}$. Then for arbitrary $v_{0}, v_{1}, v_{2}, v_{3} \in \mathfrak{U}^{1}$, i.e., such that

$$
\sum_{\lambda_{k m n}=\lambda}<\varphi_{k m n}, v_{j}>=0, j=0, \ldots, 3
$$

there exists a unique solution of problem (2) - (4).

2. Numerical Solution Algorithm. Based on the theoretical results there was developed an algorithm for numerical solution of problem (2) - (4) modelling ion-acoustic waves in a plasma in an external magnetic field, implemented in a software environment Maple 15.0. The program uses a phase space method and a modified Galerkin method.

A numerical solution algorithm is shown in a block diagram in picture 1 . The developed program allows you to:

1. Specify the sizes of the domain $\Omega$ for the mathematical model of ion-acoustic waves in a plasma in an external magnetic field.

2. Enter the parameters of the equation: $\lambda, \lambda^{\prime}, \alpha$; initial data: $v_{0}(x, y, z), v_{1}(x, y, z), v_{2}(x, y, z), v_{3}(x, y, z)$, and the order of Galerkin approximations $N$.

3. Print the numerical solution of the problem.

4. Get a graphical image of the received waves with animated distribution over time.

A detailed description of the algorithm (each block of the algorithm corresponds to one step):

Step 1. After the start of the program the number of terms in a Galerkin sum $N$, parameters $\lambda, \lambda_{1}, \alpha$, initial data $v_{0}, v_{1}, v_{2}, v_{3}$, the positive numbers $a, b, c$ and period $\tau: t \in[0, \tau]$ are entered. 
Step 2. In a cycle approximate solution $V$ is represented as the Galerkin sum $\sum_{i, j, k=1}^{N} A_{i, j, k}(t) \sin \frac{\pi i x}{a} \sin \frac{\pi j y}{b} \sin \frac{\pi k z}{c}$.

Step 3. Expression for $V$ is substituted into equation.

Step 4. Start the cycle by $i, j, k$ from 1 to $N$.

Step 5. Taking the inner product of equation by the corresponding eigenfunctions $\varphi_{i}(x), \psi_{j}(y), \chi_{k}(z)$.

Step 6 . Checking if $\lambda$ belongs to the spectrum of the Laplace operator.

If sixth step is true:

Step 7. Verification of condition $\lambda=\lambda_{1}$.

If seven step is true:

Step 8. Solving of an algebraic equation with respect to $A_{i, j, k}(t)$.

If seven step is false:

Step 9. Initial data $v_{0}, v_{1}$ are multiplied by the eigenfunctions $\varphi_{i}(x), \psi_{j}(y), \chi_{k}(z)$.

Step 10. Solving of the ordinary differential equation of the second order, corresponding to the current number $i, j, k$ in the cycle.

If the sixth step false:

Step 11. Initial data $v_{0}, v_{1}, v_{2}, v_{3}$ are scalar multiplied by the eigenfunctions $\varphi_{i}(x), \psi_{j}(y), \chi_{k}(z)$.

Step 12. Solving of the ordinary differential equation of the fourth order corresponding to the current number $i, j, k$.

Step 13. End of cycle by $i, j, k$.

Step 14. Founded Galerkin coefficients $A_{i, j, k}(t)$ are substituted into the approximate solution obtained in step 3.

Step 15. The resulting approximate solution is displayed as a graph of the solution with the animation over time from 0 to $\tau$, with chosen fixed variable (for example $z$ ).

3. Numerical Experiment. Illustrate the described algorithm by several computational examples.

Example 1. Consider the problem

$$
\begin{gathered}
v(x, y, z, t)=0, \quad(x, y, z, t) \in \partial \Omega \times \mathbb{R}, \\
v(x, y, z, 0)=\sin x \sin y \sin z, \quad v_{t}(x, y, z, 0)=10 \sin x \sin y \sin z, \\
\frac{\partial^{2} v}{\partial t^{2}}(x, y, z, 0)=3 \sin x \sin y \sin z, \quad \frac{\partial^{3} v}{\partial t^{3}}(x, y, z, 0)=\sin x \sin y \sin z, \\
(\Delta-2) \frac{\partial^{4} v}{\partial t^{4}}+(\Delta-1) \frac{\partial^{2} v}{\partial t^{2}}+\frac{\partial^{2} v}{\partial x_{3}^{2}}=0 .
\end{gathered}
$$

It is required to find the numerical solution of problem $(5)-(7)$ when $\lambda=2, \lambda^{\prime}=$ $1, \alpha=1$, in a domain $[0, \pi] \times[0, \pi] \times[0, \pi], t \in[0,2]$.

Eigenfunctions $\varphi_{i}(x), \psi_{j}(y), \chi_{k}(z)$ of the homogeneous Dirichlet problem for the Laplace operator in the domain $[0, \pi] \times[0, \pi] \times[0, \pi]$ have the form $\{\sin i x, \sin j y, \sin k z\}$. Obviously, in this case, equation (7) is not degenerate, therefore, the algorithm will take place in accordance with steps 11, 12 described in Section 2 of this article.

Graph of the solution is presented in picture 2 a. 

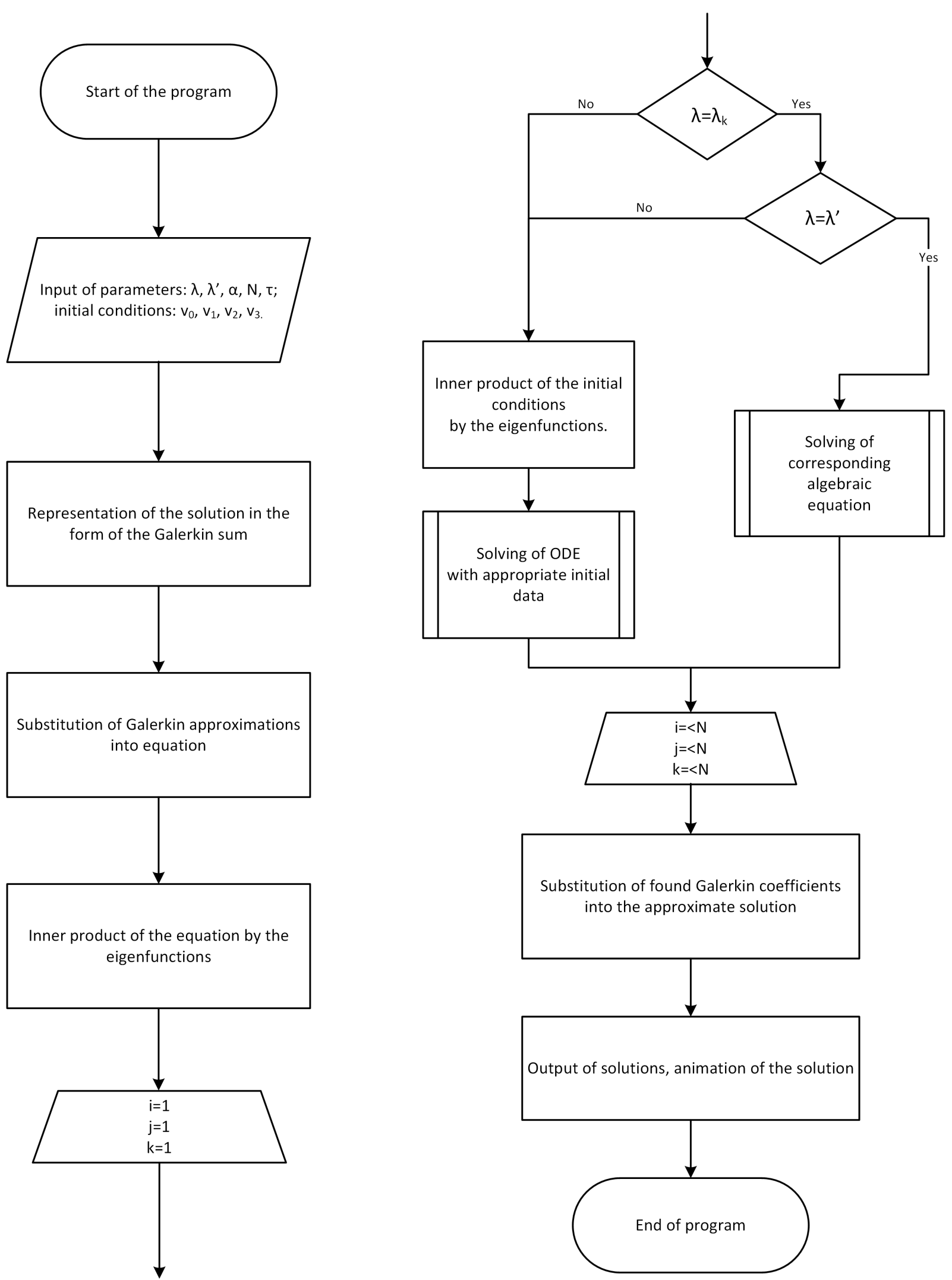

Fig. 1. A block diagram of algorithm 
Example 2. Consider the problem

$$
\begin{gathered}
v(x, y, z, t)=0, \quad(x, y, z, t) \in \partial \Omega \times \mathbb{R}, \\
v(x, y, z, 0)=8 \sin x \sin y \sin z, \quad v_{t}(x, y, z, 0)=0,1 \sin x \sin y \sin z \\
\frac{\partial^{2} v}{\partial t^{2}}(x, y, z, 0)=5 \sin x \sin y \sin z, \quad \frac{\partial^{3} v}{\partial t^{3}}(x, y, z, 0)=\sin x \sin y \sin z, \\
(\Delta+4) \frac{\partial^{4} v}{\partial t^{4}}+(\Delta+4) \frac{\partial^{2} v}{\partial t^{2}}-\frac{\partial^{2} v}{\partial x_{3}^{2}}=0 .
\end{gathered}
$$

It is required to find the numerical solution of problem $(7)-(10)$ when $\lambda=4, \lambda^{\prime}=$ $4, \alpha=1$, in a domain $[0, \pi] \times[0, \pi] \times[0, \pi], t \in[0,3]$.

Eigenfunctions $\varphi_{i}(x), \psi_{j}(y), \chi_{k}(z)$ of the homogeneous Dirichlet problem for the Laplace operator in the domain $[0, \pi] \times[0, \pi] \times[0, \pi]$ have the form $\{\sin i x, \sin j y, \sin k z\}$. Obviously, in this case, equation (10) is degenerate, therefore, the algorithm will take place in accordance with step 8 described in Section 2 of this article.

Graph of the solution is presented in picture $2 \mathrm{~b}$.

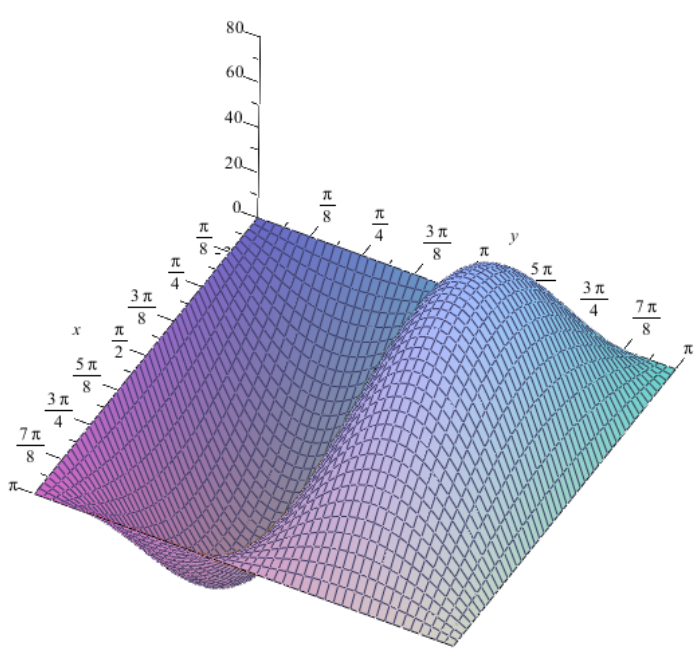

a)

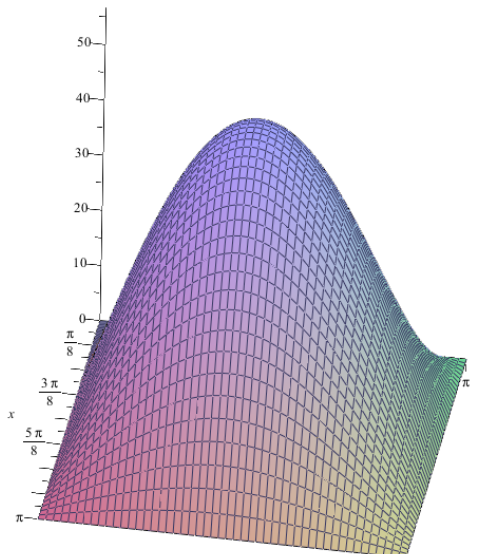

b)

Fig. 2. a) Solution from example 1; b) solution from example 2

\section{References}

1. Zamyshlyaeva A.A. Lineynye uravneniya sobolevskogo tipa vysokogo poryadka [Linear Sobolev Type Equations of High Order]. Chelyabinsk, Publ. Center of the South Ural State University, 2012.

2. Sveshnikov A.G., Al'shin A.B., Korpusov M.O., Pletner Yu.D. Lineynye $i$ nelineynye uravneniya sobolevskogo tipa [Linear and Non-Linear Equations of Sobolev Type]. Moscow, FIZMATLIT, 2007.

3. Zamyshlyaeva A.A. [Stochastic Mathematical Model of Ion-Acoustic Waves in a Plasma]. Estestvennye i tekhnicheskie nauki [Natural and Technical Sciences], 2013, no. 4, pp. 284-292. (in Russian) 
4. Zamyshlyaeva A.A. [A Mathematical Model of Ion-Acoustic Waves in a Plasma in a Magnetic Field]. Materialy mezhdunarodnoy konferentsii "Voronezhskaya zimnyaya matematicheskaya shkola S.G. Kreyna - 2014", 2014, pp. 142-144. (in Russian)

Received February 12, 2015

УДК 517.9

DOI: $10.14529 / \mathrm{mmp} 150211$

\title{
ВЫЧИСЛИТЕЛЬНЫЙ ЭКСПЕРИМЕНТ ДЛЯ ОДНОЙ МАТЕМАТИЧЕСКОЙ МОДЕЛИ ИОННО-ЗВУКОВЫХ ВОЛН
}

\author{
А.А. Замышляева, А.С. Муравъев
}

В статье рассмотрена математическая модель ионно-звуковых волн в плазме во внешнем магнитном поле. Данная математическая модель может быть редуцирована к задаче Коши для уравнения соболевского типа четвертого порядка с полиномиально $(A, p)$-ограниченным пучком операторов. Следовательно применимы абстрактные результаты по разрешимости задачи Коши для такого уравнения. В статье сформулирована теорема об однозначной разрешимости задачи Коши - Дирихле. На основе теоретических результатов был разработан алгоритм для численного решения задачи, основанный на модифицированном методе Галеркина. Алгоритм реализован в среде Maple. В конце приведены примеры, в которых решение получено при помощи разработанной программы.

Ключевые слова: математическая модель; ионно-звуковые волны; метод Галеркина.

\section{References}

1. Замышляева, А.А. Линейные уравнения соболевского типа высокого порядка / А.А. Замышляева. - Челябинск: Издательский центр ЮУрГУ, 2012.

2. Свешников, А.Г. Линейные и нелинейные уравнения соболевского типа / А.Г. Свешников, А.Б. Альшин, М.О. Корпусов, Ю.Д. Плетнер. - М.:ФИЗМАТЛИТ, 2007.

3. Замышляева, А.А. Стохастическая математическая модель ионно-звуковых волн в плазме / А.А. Замышляева // Естественные и технические науки. - 2013. - № 4. - С. 284-292.

4. Замышляева, А.А. Математическая модель ионно-звуковых волн в плазме во внешнем магнитном поле / А.А. Замышляева, А.С. Муравьев // Материалы международной конференции «Воронежская зимняя математическая школа С.Г. Крейна - 2014». - Воронеж, 2014. - C. 142-144.

Алена Александровна Замышляева, доктор физико-математических наук, доцент, кафедра «Уравнения математической физики», Южно-Уральский государственный университет (г. Челябинск, Российская Федерация), alzama@mail.ru.

Арсений Сергеевич Муравьев, магистрант, кафедра «Уравнения математической физики», Южно-Уральский государственный университет (г. Челябинск, Российская Федерация), gg.amur@gmail.com.

Поступила в редакцию 12 февраля 2015 г. 